\title{
Tyrosine-Selective Protein Alkylation Using Pi-Allylpalladium Complexes
}

\author{
S. David Tilley and Matthew B. Francis* \\ Department of Chemistry, University of California, Berkeley, CA 94720-1460, and Material Science Division, Lawrence Berkeley National
}

Labs, Berkeley, CA 94720-1460

\section{Supporting Information}

\section{General Procedures and Materials}

Unless otherwise noted, all chemicals were obtained from commercial sources and used without further purification. Analytical thin layer chromatography (TLC) was performed on EM Reagent $0.25 \mathrm{~mm}$ silica Gel $60-\mathrm{F}_{254}$ plates with visualization by ultraviolet (UV) irradiation at $254 \mathrm{~nm}$, vanillin or potassium permanganate stain. Purifications by flash chromatography were performed using EM silica gel 60 (230-400 mesh). The eluting system for each purification was determined by TLC analysis. Chromatography solvents were used without distillation. All reactions were carried out under a nitrogen atmosphere in oven dried glassware unless otherwise noted. All organic solvents were removed under reduced pressure using a rotary evaporator. Dichloromethane $\left(\mathrm{CH}_{2} \mathrm{Cl}_{2}\right)$ and acetonitrile $(\mathrm{MeCN})$ were distilled under a nitrogen atmosphere from calcium hydride. Water $\left(\mathrm{ddH}_{2} \mathrm{O}\right)$ used in biological procedures or as a reaction solvent was deionized using a NANOpure ${ }^{\mathrm{TM}}$ purification system (Barnstead, USA). Myoglobin (M 1882) from horse heart was purchased from Sigma and used without further purification. Bovine $\alpha$-Chymotrypsinogen A was purchased from MP Biomedicals, Inc. and used without further purification. The C118S mutant of H-Ras (residues 1-181) was obtained as a gift from Prof. John Kuriyan, University of California, Berkeley Department of Chemistry. $\mathrm{Pd}(\mathrm{OAc})_{2}$ and triphenylphosphine (meta-)trisulfonate (TPPTS) were purchased from Aldrich and used without further purification.

\section{Instrumentation and Sample Analysis Preparations}

NMR. ${ }^{1} \mathrm{H}$ and ${ }^{13} \mathrm{C}$ spectra were measured with a Bruker DRX-500 (500 MHz) spectrometer, a Bruker AVB-400 (400 MHz) spectrometer, or a Bruker AV-300 (300 MHz) as noted. ${ }^{1} \mathrm{H}$ NMR chemical shifts are reported as $\delta$ in units of parts per million (ppm) relative to chloroform- $d\left(\delta 7.26\right.$, singlet), methanol- $d_{4}(\delta 3.31$, pentet $)$, or dimethyl sulfoxide- $d_{6}(\delta 2.50$, pentet). Multiplicities are reported as follows: s (singlet), d (doublet), t (triplet), q (quartet), dd (doublet of doublets), dt (doublet of triplets), ddd (doublet of doublet of doublets) or $\mathrm{m}$ (multiplet). Coupling constants are reported as a $J$ value in Hertz (Hz). The number of protons (n) for a given resonance is indicated as $\mathrm{nH}$, and is based on spectral integration values. ${ }^{13} \mathrm{C}$ NMR chemical shifts are reported as $\delta$ in units of parts per million (ppm) relative to chloroform- $d\left(\delta 77.1\right.$, triplet), methanol- $d_{4}\left(\delta 49.0\right.$, septet), or dimethyl sulfoxide- $d_{6}(\delta 39.5$, septet).

Mass Spectrometry. Fast Atom Bombardment (FAB) and Electron Impact (EI) mass spectra were obtained at the UC Berkeley Mass Spectrometry Facility. Matrix assisted laser desorption-ionization time-of-flight mass spectrometry (MALDI-TOF MS) was performed on a Voyager-DE ${ }^{\mathrm{TM}}$ system (PerSeptive Biosystems, USA). All samples were co-crystallized using a sinapinic acid solution (10 $\mathrm{mg} / \mathrm{mL}$ in $7: 3 \mathrm{MeCN}: \mathrm{ddH}_{2} \mathrm{O}$ with $0.1 \%$ TFA). Electrospray LC/MS analysis was performed using an API 150EX system (Applied Biosystems, USA) equipped with a Turbospray source and an Agilent 1100 series LC pump. Protein chromatography was performed using a Phenomenex Jupiter C5 reversed phase column ( $2.0 \mathrm{~mm}$ x $150 \mathrm{~mm})$ with a MeCN: $\mathrm{ddH}_{2} \mathrm{O}$ gradient mobile phase containing $0.1 \%$ formic acid $(250 \mu \mathrm{L} / \mathrm{min})$. Protein mass reconstruction was performed on the charge ladder with Analyst software (version 1.3.1, Applied Biosystems). Prior to MS analysis, biological samples were desalted and/or separated from small molecule contaminants using $\mu \mathrm{C} 18$ 
ZipTip $^{\circledR}$ pipet tips (Millipore, USA), NAP-5 ${ }^{\mathrm{TM}}$ gel filtration columns (Amersham Biosciences, USA), or Strata C-18E ${ }^{\mathrm{TM}}$ reversed-phase columns (Phenomenex, USA) as indicated below. All MS data for protein and peptide samples were found to be within $0.1 \%$ of the expected values.

High Perfomance Liquid Chromatography. HPLC was performed on an Agilent 1100 Series HPLC System (Agilent Technologies, USA). Sample analysis for all HPLC experiments was achieved with an inline diode array detector (DAD) and an inline fluorescence detector (FLD).

Gel Analyses. For protein analysis, sodium dodecyl sulfate-polyacrylamide gel electrophoresis (SDS-PAGE) was accomplished on a Mini-Protean apparatus (Bio-Rad, USA), following the general protocol of Laemmli. ${ }^{1}$ Commercially available markers (Bio-Rad, USA) were applied to at least one lane of each gel for calculation of apparent molecular weights. Visualization of protein bands was accomplished by staining with Coomassie ${ }^{\circledR}$ Brilliant Blue R-250 (Bio-Rad, USA). Gel imaging was performed on an EpiChem3 Darkroom system (UVP, USA).

\section{Experimental}

$\overbrace{\mathrm{S} 1}^{\mathrm{Br}} \mathrm{O}$

(E)-8-Bromo-oct-2-enoic acid methyl ester (S1). Step A: To a solution of oxalyl chloride (482 $\mu \mathrm{L}, 5.52 \mathrm{mmol}$, 2.0 equiv.) in $12.5 \mathrm{~mL}$ of $\mathrm{CH}_{2} \mathrm{Cl}_{2}$ at $-78{ }^{\circ} \mathrm{C}$ was added dropwise a solution of anhydrous $\mathrm{DMSO}(0.50 \mathrm{~mL}, 7.0$ mmol, 2.5 equiv.) in $12.5 \mathrm{~mL}$ of $\mathrm{CH}_{2} \mathrm{Cl}_{2}$ that had been pre-cooled to $-78{ }^{\circ} \mathrm{C}$. To the resulting solution was slowly added a solution of 6 bromo-1-hexanol $\left(361 \mu \mathrm{L}, 2.76 \mathrm{mmol}, 1.0\right.$ equiv.) in $5 \mathrm{~mL}$ of $\mathrm{CH}_{2} \mathrm{Cl}_{2}$. The reaction mixture was stirred for 1 hour at $-78{ }^{\circ} \mathrm{C}$. At this time, $2.5 \mathrm{~mL}$ of freshly distilled $\mathrm{NEt}_{3}$ (18 mmol, 6.5 equiv.) was slowly added and the mixture warmed to room temperature. Precipitation was observed upon warming.

Step B: The phosphorane was prepared in a separate flask by addition of solid $\mathrm{NaOH}$ to an aqueous solution of (carbomethoxymethyl)triphenylphosphonium bromide ( 0.5 equiv. relative to $\mathrm{NaOH}$ ). The resulting solution was extracted with $\mathrm{CH}_{2} \mathrm{Cl}_{2}$ and the organic layer was dried over $\mathrm{Na}_{2} \mathrm{SO}_{4}$ and concentrated. A portion of the resulting white solid (1.52 g, $4.55 \mathrm{mmol}, 1.65$ equiv.) was added to the reaction mixture produced in $A$, and this mixture stirred under argon overnight. The orange reaction mixture was then washed twice with $0.1 \mathrm{M} \mathrm{HCl}$, once with saturated $\mathrm{NaHCO}_{3}$, once with water, and once with brine. The organic layer was dried over anhydrous $\mathrm{Na}_{2} \mathrm{SO}_{4}$ and concentrated to yield a flaky, orange solid that was purified by flash chromatography (hexanes/EtOAc 9:1), yielding 318 mg of a pale yellow oil (identified as the trans-isomer, 52\% yield), which was used without further purification. Note: Longer reaction times after addition of the phosphorane resulted in chloride incorporation: ${ }^{1} \mathrm{H} \mathrm{NMR}\left(400 \mathrm{MHz}, \mathrm{CDCl}_{3}\right): \delta, 1.48(\mathrm{~m}, 4 \mathrm{H}), 1.86(\mathrm{~m}, 2 \mathrm{H}), 2.21(\mathrm{~m}, 2 \mathrm{H})$, $3.40(\mathrm{t}, 2 \mathrm{H}, J=7.0 \mathrm{~Hz}), 3.72(\mathrm{~s}, 3 \mathrm{H}), 5.82(\mathrm{~d}, 1 \mathrm{H}, 15.5 \mathrm{~Hz}), 6.95(\mathrm{dt}, 1 \mathrm{H}, J=7.0 \mathrm{~Hz}, 15.5 \mathrm{~Hz}) .{ }^{13} \mathrm{C} \mathrm{NMR}(100 \mathrm{MHz}, \mathrm{CDCl} 3): \delta, 27.0,27.5$, 31.8, 32.4, 33.3, 51.0, 121.0, 148.7, 166.4. LRMS (EI+) calculated for $\mathrm{C}_{9} \mathrm{H}_{15} \mathrm{BrO}_{2}\left([\mathrm{M}]^{+},{ }^{79} \mathrm{Br}\right) 234,\left([\mathrm{M}]^{+},{ }^{81} \mathrm{Br}\right) 236$, found $234,236$.

Br

S2
(E)-8-Bromo-oct-2-en-1-ol (S2). To a stirred solution of $\mathbf{S 1}$ (1.56 g, $6.63 \mathrm{mmol}, 1.0$ equiv.) in $22 \mathrm{~mL} \mathrm{of} \mathrm{CH}_{2} \mathrm{Cl}_{2}$ at $-78{ }^{\circ} \mathrm{C}$ was added dropwise $20 \mathrm{~mL}$ of a $1.0 \mathrm{M}$ solution of DIBAL-H in hexanes $(20 \mathrm{mmol}, 3.0$ equiv. $)$. After

stirring for 1.5 hours at $-78{ }^{\circ} \mathrm{C}$, the solution was returned to room temperature concurrent with the dropwise addition of a saturated $\mathrm{NH}_{4} \mathrm{Cl}$ solution. The initially deep yellow reaction mixture became colorless and bubbled vigorously. After the bubbling ceased, the liquid turned immediately into a clear gel. Addition of $10 \mathrm{~mL}$ of $\mathrm{CH}_{2} \mathrm{Cl}_{2}$ resulted in the formation of white clumps that were removed via filtration of the biphasic mixture. The organic layer was isolated and washed with brine. Drying over $\mathrm{Na}_{2} \mathrm{SO}_{4}$ followed by removal of the solvent yielded $1.14 \mathrm{~g}$ of $\mathbf{S 2}$ as a yellow oil that needed no further purification ( $83 \%$ yield): ${ }^{1} \mathrm{H} \mathrm{NMR}\left(400 \mathrm{MHz}, \mathrm{CDCl}_{3}\right): \delta, 1.42(\mathrm{br} \mathrm{s}, 4 \mathrm{H}), 1.53$ $(\mathrm{s}, 1 \mathrm{H}), 1.85(\mathrm{~m}, 2 \mathrm{H}), 2.05(\mathrm{~m}, 2 \mathrm{H}), 3.40(\mathrm{t}, 2 \mathrm{H}, J=6.8 \mathrm{~Hz}), 4.07(\mathrm{~d}, 2 \mathrm{H}, J=6.0 \mathrm{~Hz}), 5.67(\mathrm{~m}, 2 \mathrm{H}) .{ }^{13} \mathrm{C} \mathrm{NMR}\left(100 \mathrm{MHz}, \mathrm{CDCl}_{3}\right): \delta, 27.6$, 28.2, 31.9, 32.6, 33.9, 63.7, 129.2, 132.7. LRMS (EI+) calculated for $\mathrm{C}_{8} \mathrm{H}_{15} \mathrm{BrO}\left([\mathrm{M}]^{+},{ }^{79} \mathrm{Br}\right) 206,\left([\mathrm{M}]^{+},{ }^{81} \mathrm{Br}\right) 208$, found $205,207$. 


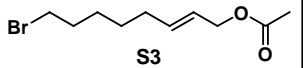

Acetic acid (E)-8-bromo-oct-2-enyl ester (S3). To a stirred solution of S2 (0.245 g, $1.18 \mathrm{mmol}, 1.0$ equiv.), acetic anhydride $(0.224 \mathrm{~mL}, 2.37 \mathrm{mmol}, 2.0$ equiv.) and DMAP (0.01 g, $0.09 \mathrm{mmol}, 0.08$ equiv.) was added dropwise a solution of pyridine/ $\mathrm{CH}_{2} \mathrm{Cl}_{2}(1: 1)$ at $0{ }^{\circ} \mathrm{C}$. After stirring for 30 minutes at $0{ }^{\circ} \mathrm{C}$, the solution was removed from the ice bath and stirred overnight at room temperature. The reaction mixture was then poured into $20 \mathrm{~mL}$ of $4 \mathrm{~N} \mathrm{HCl}$ and extracted three times with ether. The combined organic layers were washed once with dilute aqueous $\mathrm{HCl}$, once with saturated $\mathrm{NaHCO}_{3}$, once with water and once with brine. Drying of the organic layer over $\mathrm{Na}_{2} \mathrm{SO}_{4}$ and concentration yielded $0.212 \mathrm{~g}$ of $\mathbf{S 3}$ as a pale yellow oil that needed no further purification (72\% yield): ${ }^{1} \mathrm{H}$ NMR $\left(300 \mathrm{MHz} \mathrm{CDCl}_{3}\right): \delta, 1.40(\mathrm{~m}, 4 \mathrm{H}), 1.82(\mathrm{~m}, 2 \mathrm{H}), 2.02(\mathrm{~s}, 3 \mathrm{H}), 2.05(\mathrm{~m}, 2 \mathrm{H}), 3.37(\mathrm{t}, 2 \mathrm{H}, J=6.6 \mathrm{~Hz})$, $4.47(\mathrm{~d}, 2 \mathrm{H}, 6.3 \mathrm{~Hz}), 5.56(\mathrm{~m}, 1 \mathrm{H}), 5.70(\mathrm{~m}, 1 \mathrm{H}) .{ }^{13} \mathrm{C} \mathrm{NMR}\left(75 \mathrm{MHz}, \mathrm{CDCl}_{3}\right): \delta, 21.3,27.5,27.9,32.3,32.8,34.0,65.4,124.4,136.2$, 171.1 .

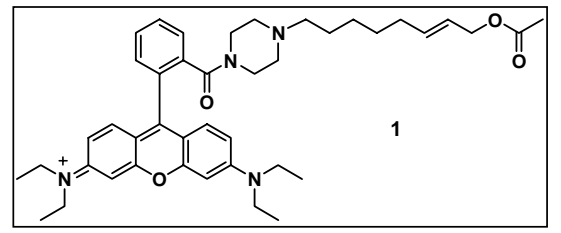

Rhodamine B 4-[(O)-acyl-8-oct-6-enol]piperazine amide, chloride salt (1). To a solution of $\mathbf{S 3}(0.271 \mathrm{~g}, 1.09 \mathrm{mmol}, 5.0$ equiv.) in $2 \mathrm{~mL}$ of DMF was added DIPEA (114 $\mu \mathrm{L}, 0.652$ mmol, 3.0 equiv.) and rhodamine piperazine amide $\left(0.117 \mathrm{~g}, 0.218 \mathrm{mmol}, 1.0\right.$ equiv.). ${ }^{2}$ The reaction mixture was stirred at $45{ }^{\circ} \mathrm{C}$ for 5 hours and then stirred overnight at room temperature. The DMF was removed in vacuo and the remaining residue dissolved in $1 \mathrm{~mL}$ of $\mathrm{MeOH}$. This solution was added dropwise to a large volume of diethyl ether to precipitate the product (1), which was isolated as an iridescent purple and gold powder $\left(0.117 \mathrm{~g}, 72 \%\right.$ yield): ${ }^{1} \mathrm{H}$ NMR $\left(400 \mathrm{MHz}, \mathrm{CD}_{3} \mathrm{OD}\right): \delta, 1.32(\mathrm{t}, 12 \mathrm{H}, J=7.0 \mathrm{~Hz}), 1.37(\mathrm{~m}, 2 \mathrm{H}), 1.44(\mathrm{~m}$, 2H), 1.70 (m, 2H), 2.02 (s, 3H), 2.09 (m, 2H), 3.09 (m, 2H), 2.6-3.8 (br, 8H), 3.70 (q, 8H, J = 7.3 Hz), 4.49 (d, 2H, J=6.2 Hz), 5.58 (m, $1 \mathrm{H}), 5.76(\mathrm{~m}, 1 \mathrm{H}), 6.98(\mathrm{~d}, 2 \mathrm{H}, J=2.3 \mathrm{~Hz}), 7.07(\mathrm{dd}, 2 \mathrm{H}, J=2.3,9.5 \mathrm{~Hz}), 7.26(\mathrm{~d}, 2 \mathrm{H}, J=9.5 \mathrm{~Hz}), 7.54(\mathrm{~m}, 1 \mathrm{H}), 7.78(\mathrm{~m}, 3 \mathrm{H}) .{ }^{13} \mathrm{C} \mathrm{NMR}$ (100 MHz, $\left.\mathrm{CD}_{3} \mathrm{OD}\right): \delta, 11.4,19.4,23.3,25.5,28.0,31.4,45.5,56.7,64.7,96.0,114.0,124.5,127.4,130.1,130.3,130.6,131.1,131.6$, 134.1, 135.0, 155.2, 155.9, 157.9, 168.0. HRMS (MALDI-TOF MS+) calculated for $\mathrm{C}_{42} \mathrm{H}_{55} \mathrm{~N}_{4} \mathrm{O}_{4}\left([\mathrm{M}]^{+}\right.$) 679.4218, found 679.4223.

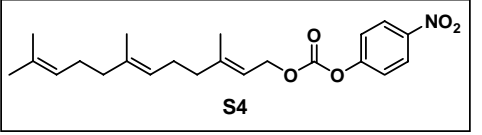

(E,E)-Farnesyl 4-nitrophenyl carbonate (S4). To a solution of 4-nitrophenyl chloroformate (2.0 g, 9.9 mmol, 1.1 equiv. $)$ in $20 \mathrm{~mL}$ of $\mathrm{CH}_{2} \mathrm{Cl}_{2}$ was added dropwise a solution of farnesol $(2.3 \mathrm{~mL}$, $9.0 \mathrm{mmol}, 1.0$ equiv.) and freshly distilled pyridine (1.46 mL, $18 \mathrm{mmol}, 2.0$ equiv.) in $20 \mathrm{~mL}$ of $\mathrm{CH}_{2} \mathrm{Cl}_{2}$, resulting in an initially cloudy solution that quickly cleared. After 5 minutes, the reaction mixture was washed three times with 0.1 $\mathrm{M} \mathrm{HCl}$, six times with saturated $\mathrm{NaHCO}_{3}$ (each wash was yellow), once with water, and once with brine. Drying of the organic layer over $\mathrm{Na}_{2} \mathrm{SO}_{4}$ and concentration yielded $\mathrm{S} 4$ as a viscous yellow oil $(3.58 \mathrm{~g})$, which contained small amounts of nitrophenol and $\mathrm{CH}_{2} \mathrm{Cl}_{2}$ impurities (drying in vacuo did not reduce the amount of $\mathrm{CH}_{2} \mathrm{Cl}_{2}$ impurity by ${ }^{1} \mathrm{H} \mathrm{NMR}$ ). It was estimated from the ${ }^{1} \mathrm{H}$ NMR spectrum that the oil contained $87 \% \mathbf{S 4}$ by mass $\left(3.11 \mathrm{~g}, 89 \%\right.$ yield). This material was taken on without further purification: ${ }^{1} \mathrm{H}$ NMR $(300 \mathrm{MHz}$, $\left.\mathrm{CDCl}_{3}\right): \delta, 1.62(\mathrm{~s}, 6 \mathrm{H}), 1.67(\mathrm{~s}, 3 \mathrm{H}), 1.77(\mathrm{~s}, 3 \mathrm{H}), 2.97(\mathrm{~m}, 8 \mathrm{H}), 4.80(\mathrm{~d}, 2 \mathrm{H}, J=7.2 \mathrm{~Hz}), 5.08(\mathrm{~m}, 2 \mathrm{H}), 5.44(\mathrm{t}, 1 \mathrm{H}, J=7.2 \mathrm{~Hz}), 7.38(\mathrm{~d}$, $2 \mathrm{H}, J=9.3 \mathrm{~Hz}), 8.28(\mathrm{~d}, 2 \mathrm{H}, J=9.3 \mathrm{~Hz}) .{ }^{13} \mathrm{C} \mathrm{NMR}\left(75 \mathrm{MHz}, \mathrm{CDCl}_{3}\right): \delta, 16.3,16.9,17.9,26.0,26.3,27.0,39.8,40.0,66.3,117.1,122.0$, $123.6,124.5,125.5,131.6,135.9,145.1,145.6,152.8,155.9$.

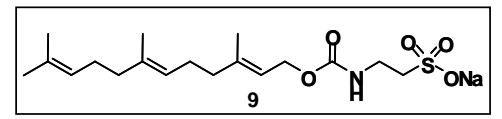

(E,E)-Farnesyl taurine carbamate, sodium salt (9). To a solution of $\mathbf{S 4}(3.11 \mathrm{~g}, 8.03 \mathrm{mmol}$, 1.0 equiv.) in $8 \mathrm{~mL}$ of DMF was added sodium taurinate $(1.21 \mathrm{~g}, 8.22 \mathrm{mmol}, 1.03$ equiv.), resulting in a yellow heterogeneous mixture that was stirred for 24 hours at room temperature.

The orange-yellow mixture was then transferred to a $1 \mathrm{~L}$ flask using $\mathrm{MeOH}$ rinses and the solvents were carefully removed under reduced pressure (the mixture was soapy and bubbly). The residue was then dried in vacuo. The yellow residue was taken up in MeOH and the remaining solids removed by centrifugation (filtration was unsuccessful). The $\mathrm{MeOH}$ was removed under reduced pressure and the yellow solid was transferred to the top of a Celite column. The solid was triturated twice with $\mathrm{MeCN}$, four times with a mixture of acetic acid in MeCN (10-25\%), and finally three times with MeCN, leaving the product (9) as an insoluble cream-colored solid on the frit. The product 
was eluted from the Celite column with $\mathrm{MeOH}$, which after concentration yielded 9 as a white powder $\left(1.32 \mathrm{~g}, 41 \%\right.$ yield): ${ }^{1} \mathrm{H}$ NMR $(500$ $\left.\mathrm{MHz}, \mathrm{D}_{2} \mathrm{O}\right): \delta, 1.54(\mathrm{~s}, 3 \mathrm{H}), 1.55(\mathrm{~s}, 3 \mathrm{H}), 1.61(\mathrm{~s}, 3 \mathrm{H}), 1.66(\mathrm{~s}, 3 \mathrm{H}), 1.92(\mathrm{~m}, 2 \mathrm{H}), 1.99(\mathrm{~m}, 6 \mathrm{H}), 3.05(\mathrm{t}, 2 \mathrm{H}, J=7.0 \mathrm{~Hz}), 3.48(\mathrm{t}, 2 \mathrm{H}, J=$ $7.0 \mathrm{~Hz}), 4.52(\mathrm{~d}, 2 \mathrm{H}, J=6.5 \mathrm{~Hz}), 5.05(\mathrm{~m}, 2 \mathrm{H}), 5.28(\mathrm{~m}, 1 \mathrm{H}) .{ }^{13} \mathrm{C} \mathrm{NMR}\left(125 \mathrm{MHz}, \mathrm{D}_{2} \mathrm{O}\right): \delta, 15.6,15.9,17.2,25.2,26.2,26.6,36.3,39.4$, 39.5, 50.3, 61.8, 118.6, 123.9, 124.4, 130.6, 134.8, 141.7, 157.7. HRMS (FAB+) calculated for $\mathrm{C}_{18} \mathrm{H}_{30} \mathrm{NNa}_{2} \mathrm{O}_{5} \mathrm{~S}\left(\left[\mathrm{M}+\mathrm{Na}^{+}\right) 418.1640\right.$, found 418.1650 .

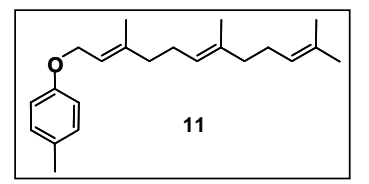

(O)-Farnesyl-p-cresol (11). A $50 \mathrm{~mL}$ roundbottom flask was charged with cresol (0.136 g, $1.26 \mathrm{mmol}, 10$ equiv.), 9 (0.050 g, $0.126 \mathrm{mmol}, 1.0$ equiv.), palladium acetate (0.028 g, $0.126 \mathrm{mmol}, 1.0$ equiv.), TPPTS ( $0.143 \mathrm{mg}, 0.252 \mathrm{mmol}, 2.0$ equiv.) and DIPEA (0.220 mL, $1.26 \mathrm{mmol}, 10$ equiv.). The addition of $12.6 \mathrm{~mL}$ of $\mathrm{H}_{2} \mathrm{O}$ resulted in a heterogeneous, frothy orange mixture. Progress of the reaction was monitored by bubbling $\mathrm{N}_{2}$ through the reaction mixture and observing the formation of bubbles. The mixture ceased to produce bubbles after 30 minutes and became increasingly heterogeneous. The resulting aqueous mixture was extracted twice with EtOAc, although separation of the layers was incomplete. The combined organic layers were washed with brine and dried over $\mathrm{Na}_{2} \mathrm{SO}_{4}$. The resulting material was purified by flash chromatography (hexanes/EtOAc 99:1) to yield the product (11) as a yellow oil (10 mg, 26\% yield based on 9). The remainder of the material in the reaction consisted of a mixture of farnesenes and cresol (no products resulting from the rearrangement of farnesylated cresol were observed): ${ }^{1} \mathrm{H}$ NMR $\left(500 \mathrm{MHz}, \mathrm{CDCl}_{3}\right): \delta, 1.66(\mathrm{~s}, 6 \mathrm{H}), 1.74(\mathrm{~s}, 3 \mathrm{H}), 1.79(\mathrm{~s}, 3 \mathrm{H}), 2.04(\mathrm{~m}, 2 \mathrm{H}), 2.16(\mathrm{~m}, 4 \mathrm{H}), 2.22(\mathrm{~m}, 2 \mathrm{H}), 2.33(\mathrm{~s}$, $\left.3 \mathrm{H}), 4.56(\mathrm{~d}, 2 \mathrm{H}, J=6.5 \mathrm{~Hz}), 5.16(\mathrm{~m}, 2 \mathrm{H}), 5.56(\mathrm{~m}, 1 \mathrm{H}), 6.87(\mathrm{~d}, 2 \mathrm{H}, J=8.5 \mathrm{~Hz}), 7.12(\mathrm{~d}, 2 \mathrm{H}, J=8.4 \mathrm{~Hz}) .{ }^{13} \mathrm{C} \mathrm{NMR}(125 \mathrm{MHz}, \mathrm{CDCl})\right)$ $\delta, 15.9,16.6,17.6,20.4,25.6,26.2,26.7,39.5,39.6,64.8,114.4,119.7,123.7,124.3,129.6,129.7,131.2,135.3,140.8,156.7$. HRMS (EI+) calculated for $\mathrm{C}_{22} \mathrm{H}_{32} \mathrm{O}\left([\mathrm{M}]^{+}\right) 312.2453$, found 312.2448 .

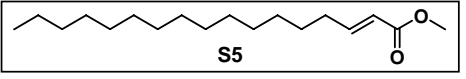

(E)-Heptadec-2-enoic acid methyl ester (S5). To a solution of oxalyl chloride (1.9 mL, $22 \mathrm{mmol}$, 2.0 equiv.) in $50 \mathrm{~mL}$ of $\mathrm{CH}_{2} \mathrm{Cl}_{2}$ at $-78{ }^{\circ} \mathrm{C}$ was added a solution of anhydrous DMSO $(2.0 \mathrm{~mL}, 28$ mmol, 2.5 equiv.) in $50 \mathrm{~mL}$ of $\mathrm{CH}_{2} \mathrm{Cl}_{2}$. To this reaction mixture was added dropwise a solution of 1-pentadecanol (2.52 g, $11.0 \mathrm{mmol}, 1.0$ equiv.) in $20 \mathrm{~mL}$ of $\mathrm{CH}_{2} \mathrm{Cl}_{2}$. A white precipitate was observed and the heterogeneous mixture was stirred for 1 hour at $-78{ }^{\circ} \mathrm{C}$. Freshly distilled $\mathrm{NEt}_{3}(9.3 \mathrm{~mL}, 67 \mathrm{mmol}, 6.1$ equiv.) was then added slowly via syringe and the reaction mixture was warmed to room temperature over $30 \mathrm{~min}$. During this time the phosphorane was prepared according to the procedure described in Step B of the experimental for compound S1. The phosphorane (5.9 g, $18 \mathrm{mmol}, 1.6$ equiv.) was added to the reaction mixture, which was stirred overnight under argon. The reaction mixture was then washed twice with $0.1 \mathrm{M} \mathrm{HCl}$, once with saturated $\mathrm{NaHCO}_{3}$, once with water, and once with brine. Drying over $\mathrm{Na}_{2} \mathrm{SO}_{4}$ and concentration yielded a flaky yellow solid. The material was filtered through a plug of silica (hexanes/EtOAc 9:1) to yield pure $\mathbf{S 5}$ as a pale yellow oil (2.97 g, trans- isomer, 95\% yield): ${ }^{1} \mathrm{H} \mathrm{NMR}\left(500 \mathrm{MHz}, \mathrm{CDCl}_{3}\right): \delta, 0.83(\mathrm{t}, 3 \mathrm{H}, J=7.5 \mathrm{~Hz}), 1.19-1.28$ $(\mathrm{m}, 22 \mathrm{H}), 1.39(\mathrm{~m}, 2 \mathrm{H}), 2.14(\mathrm{~m}, 2 \mathrm{H}), 3.66(\mathrm{~s}, 3 \mathrm{H}), 5.76(\mathrm{~d}, 1 \mathrm{H}, J=15.5 \mathrm{~Hz}), 6.92(\mathrm{dt}, 1 \mathrm{H}, J=7.0 \mathrm{~Hz}, 15.5 \mathrm{~Hz}) .{ }^{13} \mathrm{C} \mathrm{NMR}(125 \mathrm{MHz}$ $\left.\mathrm{CDCl}_{3}\right): \delta, 14.0,22.6,27.9,29.1,29.3,29.3,29.5,29.5-29.7(\mathrm{~m}), 31.9,32.1,51.1,120.7,149.6,167.0$. HRMS (FAB+) calculated for $\mathrm{C}_{18} \mathrm{H}_{35} \mathrm{O}_{2}\left([\mathrm{M}+\mathrm{H}]^{+}\right)$283.2637, found 283.2639.

SOH

dropwise over 7 minutes. The reaction mixture was then warmed to room temperature and stirred for 4 hours. The addition of saturated $\mathrm{NH}_{4} \mathrm{Cl}$ solution caused the reaction mixture to bubble vigorously and subsequently solidify. $\mathrm{Additional} \mathrm{CH}_{2} \mathrm{Cl}_{2} \mathrm{Was} \mathrm{added}(10-20 \mathrm{~mL})$ and the white salts were removed by filtration. The organic layer was washed with brine and dried over $\mathrm{Na}_{2} \mathrm{SO}_{4}$. $\mathrm{Concentration}_{\mathbf{2}} \mathrm{Ielded}_{\mathbf{S 6}}$ as a white solid that needed no further purification $(0.745 \mathrm{~g}, 92 \%$ yield $\left.):{ }^{1} \mathrm{H} \mathrm{NMR}\left(300 \mathrm{MHz}^{\mathrm{CDCl}}\right)_{3}\right) \delta, 0.85(\mathrm{t}, 3 \mathrm{H}, \mathrm{J}=6.9 \mathrm{~Hz}), 1.23(\mathrm{~s}, 22 \mathrm{H})$, 
$1.34(\mathrm{~m}, 2 \mathrm{H}), 2.00(\mathrm{~m}, 2 \mathrm{H}), 2.38(\mathrm{~s}, 1 \mathrm{H}), 4.02(\mathrm{~m}, 2 \mathrm{H}), 5.60(\mathrm{~m}, 2 \mathrm{H}) .{ }^{13} \mathrm{C} \mathrm{NMR}\left(75 \mathrm{MHz}, \mathrm{CDCl}_{3}\right): \delta, 14.0,22.6,29.1,29.2,29.3,29.5$, $29.6,29.7,31.9,32.2,63.5,128.8,133.1$.

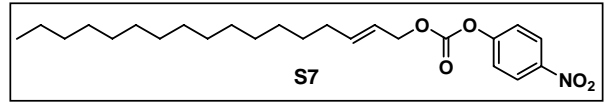

(E)-Heptadec-2-enyl 4-nitrophenyl carbonate (S7). To a solution of S6 (0.745 g, 2.93 mmol, 1.0 equiv.) and pyridine ( $0.5 \mathrm{~mL}, 6 \mathrm{mmol}, 2$ equiv. $)$ in $7 \mathrm{~mL}$ of $\mathrm{CH}_{2} \mathrm{Cl}_{2}$ was added dropwise a solution of 4-nitrophenyl chloroformate $\left(0.661 \mathrm{~g}, 3.24 \mathrm{mmol}, 1.1\right.$ equiv.) in $7 \mathrm{~mL}$ of $\mathrm{CH}_{2} \mathrm{Cl}_{2}$. The reaction was complete after 10 minutes as observed by TLC. The reaction mixture was washed three times with $0.1 \mathrm{M} \mathrm{HCl}$, twice with saturated $\mathrm{NaHCO}_{3}$, once with $1 \mathrm{M} \mathrm{K}_{2} \mathrm{CO}_{3}$, twice with water, and once with brine. Drying over $\mathrm{Na}_{2} \mathrm{SO}_{4}$ and concentration yielded $\mathbf{S} 7$ as a white solid (1.12 $\mathrm{g}, 91 \%$ yield): ${ }^{1} \mathrm{H}$ NMR (300 MHz, $\left.\mathrm{CDCl}_{3}\right): \delta, 0.87(\mathrm{t}, 3 \mathrm{H}, J=6.3 \mathrm{~Hz}), 1.25(\mathrm{~s}, 22 \mathrm{H}), 1.39(\mathrm{~m}, 2 \mathrm{H}), 2.08(\mathrm{~m}, 2 \mathrm{H}), 4.70(\mathrm{~d}, 2 \mathrm{H}, J=6.6 \mathrm{~Hz}), 5.61(\mathrm{~m}, 1 \mathrm{H})$, $5.90(\mathrm{~m}, 1 \mathrm{H}), 7.37(\mathrm{~d}, 2 \mathrm{H}, J=9.0 \mathrm{~Hz}), 8.28(\mathrm{~d}, 2 \mathrm{H}, J=9.0 \mathrm{~Hz}) .{ }^{13} \mathrm{C} \mathrm{NMR}\left(75 \mathrm{MHz}, \mathrm{CDCl}_{3}\right): \delta, 14.1,22.6,28.7,29.1,29.3,29.4,29.55$, $29.62,29.64,31.9,32.2,70.1,121.7,125.2,139.1,145.3,152.3,154.8,155.6$.

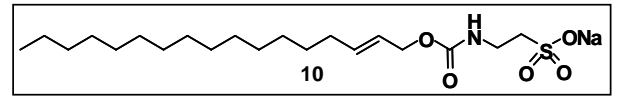

(E)-Heptadec-2-enyl taurine carbamate, sodium salt (10). To a solution of $\mathbf{S 7}$ (0.805 g, $1.92 \mathrm{mmol}, 1.0$ equiv.) in $4.8 \mathrm{~mL}$ of anhydrous DMF was added sodium taurinate $(0.339 \mathrm{~g}, 2.30 \mathrm{mmol}, 1.2$ equiv.). The yellow, heterogeneous mixture was stirred at room temperature for 8 hours. The reaction mixture was then transferred to a $1 \mathrm{~L}$ flask using $\mathrm{MeOH}$ rinses and the solvents were carefully removed under reduced pressure. The viscous yellow mixture was taken up in $\mathrm{MeOH}$ and the solids removed by centrifugation (filtration was unsuccessful). The MeOH was removed under reduced pressure and the yellow solid was transferred to the top of a Celite column. The solid was triturated twice with $\mathrm{MeCN}$, four times with a mixture of acetic acid in $\mathrm{MeCN}(10-25 \%)$, and finally three times with MeCN, leaving the product (10) as an insoluble cream-colored solid on the frit. The product was eluted from the Celite column with $\mathrm{MeOH}$, which after concentration yielded $\mathbf{1 0}$ as a white powder $\left(0.33 \mathrm{~g}, 40 \%\right.$ yield): ${ }^{1} \mathrm{H}$ NMR (400 MHz, $d^{6}$-DMSO): $\delta, 0.85(\mathrm{t}, 3 \mathrm{H}, J=6.4 \mathrm{~Hz}), 1.23(\mathrm{~m}, 22 \mathrm{H}), 1.31(\mathrm{~m}, 2 \mathrm{H}), 1.99(\mathrm{~m}$, $2 \mathrm{H}), 2.51(\mathrm{~m}, 2 \mathrm{H}), 3.21(\mathrm{~m}, 2 \mathrm{H}), 4.36(\mathrm{~d}, 2 \mathrm{H}, J=6.0 \mathrm{~Hz}), 5.51(\mathrm{~m}, 1 \mathrm{H}), 5.69(\mathrm{~m}, 1 \mathrm{H}), 6.91(\mathrm{~m}, 1 \mathrm{H}) .{ }^{13} \mathrm{C} \mathrm{NMR}\left(125 \mathrm{MHz}, d^{6}-\mathrm{DMSO}\right): \delta$, $14.4,22.5,28.7,29.0,29.1,29.3,29.4,29.5,31.7,32.0,37.6,51.1,64.6,125.5,135.1,156.1$. HRMS (FAB + ) calculated for $\mathrm{C}_{20} \mathrm{H}_{38} \mathrm{NNa}_{2} \mathrm{O}_{5} \mathrm{~S}\left([\mathrm{M}+\mathrm{Na}]^{+}\right) 450.2266$, found 450.2257 .

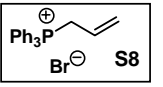

Allyltriphenylphosphonium bromide (S8). To a solution of triphenylphosphine (50.05 g, $0.19 \mathrm{~mol}, 1.0$ equiv.) in $180 \mathrm{~mL}$ acetone was added allyl bromide $(16.5 \mathrm{~mL}, 0.19 \mathrm{~mol}, 1.0$ equiv.) in one portion. After 2 hours reaction time, a thick slurry was observed, and the mixture was stirred for 24 hours at room temperature. The solids were removed by filtration and thoroughly washed with acetone. The filter cake was dried in vacuo to yield the product (S8) as a white powder $(62.67 \mathrm{~g}, 86 \% \mathrm{yield})$ : ${ }^{1} \mathrm{H} \mathrm{NMR}(400 \mathrm{MHz}$, $\left.\mathrm{CD}_{3} \mathrm{OD}\right): \delta, 4.47(\mathrm{dd}, 2 \mathrm{H}, J=7.2,16.0 \mathrm{~Hz}), 5.45(\mathrm{~m}, 2 \mathrm{H}), 5.83(\mathrm{~m}, 1 \mathrm{H}), 7.70-7.95(\mathrm{~m}, 15 \mathrm{H})$. This is in accordance with the data reported by Jugé. ${ }^{3}$

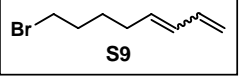

(E/Z)-8-Bromo-oct-1,3-diene (S9). Ozone was bubbled through a solution of 6-bromo-1-hexene (1.00 g, $6.13 \mathrm{mmol}$, 1.0 equiv.) in $4 \mathrm{~mL}$ of $\mathrm{CH}_{2} \mathrm{Cl}_{2}$ at $-78{ }^{\circ} \mathrm{C}$ until a pale blue color persisted. The reaction mixture was then warmed to room temperature and sparged with nitrogen until the solution was colorless. Triphenylphosphine (3.23 g, $12.3 \mathrm{mmol}, 2.0 \mathrm{equiv}$.) was then added and the solution was stirred for 30 minutes at room temperature. Concentration yielded an orange liquid that was filtered through a plug of silica (9:1 hexanes/ethyl acetate) and concentrated to give an orange oil $(0.333 \mathrm{~g})$ that contained both 5-bromo-pentanal and triphenylphosphine. To this mixture was added an excess of $\mathbf{S 8}$ (4.6 g, $12 \mathrm{mmol}, 2.0$ equiv.), $315 \mathrm{~mL}$ of $5 \mathrm{M} \mathrm{NaOH}$ and $105 \mathrm{~mL}$ of benzene, ${ }^{4}$ and the biphasic mixture was stirred vigorously for 24 hours. The bright yellow benzene layer was isolated and washed once with water, once with brine, dried over $\mathrm{Na}_{2} \mathrm{SO}_{4}$, and concentrated. The remaining residue was purified by flash chromatography (99:1 hexanes/ethyl acetate), to yield $\mathbf{S 9}$ as a 1:1 mixture of cis- and trans- isomers $\left(0.23 \mathrm{~g}, 20 \%\right.$ yield): ${ }^{1} \mathrm{H} \mathrm{NMR}(400 \mathrm{MHz}, \mathrm{CDCl} 3): \delta, 1.58(\mathrm{~m}$, 4H), $1.88(\mathrm{~m}, 4 \mathrm{H}), 2.12(\mathrm{~m}, 2 \mathrm{H}), 2.21(\mathrm{~m}, 2 \mathrm{H}), 3.41(\mathrm{t}, 4 \mathrm{H}, J=6.8 \mathrm{~Hz}), 4.98(\mathrm{~d}, 1 \mathrm{H}, J=10.4 \mathrm{~Hz}), 5.12(\mathrm{~m}, 2 \mathrm{H}), 5.21(\mathrm{~d}, 1 \mathrm{H}, J=16.8 \mathrm{~Hz})$, 
$5.42(\mathrm{~m}, 1 \mathrm{H}), 5.68(\mathrm{dt}, 1 \mathrm{H}, J=8.0,15.2 \mathrm{~Hz}), 6.05(\mathrm{~m}, 2 \mathrm{H}), 6.32(\mathrm{ddd}, 1 \mathrm{H}, J=10.0,10.0,16.6 \mathrm{~Hz}), 6.62(\mathrm{ddd}, 1 \mathrm{H}, J=10.0,10.5,16.6 \mathrm{~Hz})$. This is in accordance with the data provided for both the cis- and trans- isomers as reported by Sato. ${ }^{5}$ Integrations are reported such that the olefinic protons are calibrated to 1 . Thus, integrations for protons in which the cis- and trans- isomers overlap provide twice the signal.

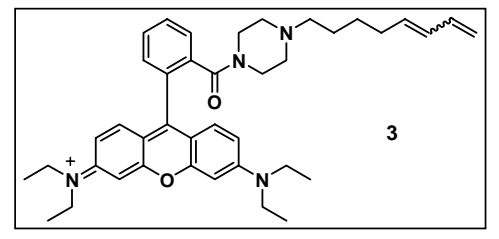

Rhodamine B 4-[(E/Z)-octa-5,7-diene]piperazine amide, chloride salt (3). A $10 \mathrm{~mL}$ roundbottom flask was charged with diene $\mathbf{S 9}(0.82 \mathrm{~g}, 4.4 \mathrm{mmol}, 5.0$ equiv), rhodamine piperazine amide (0.48 g, $0.87 \mathrm{mmol}, 1.0$ equiv), ${ }^{2}$ DIPEA (0.45 mL, $2.6 \mathrm{mmol}, 3.0$ equiv.), and $3 \mathrm{~mL}$ of DMF. The dark purple solution was stirred at room temperature for 38 hours. The liquids were distilled off and the resulting iridescent purple-golden solid was dissolved in $4 \mathrm{~mL}$ of $\mathrm{MeOH}$ and precipitated from a large volume of ether. The purple solid was collected on filter paper and determined to be $90 \%$ pure by HPLC ( $0.49 \mathrm{~g}$, 90\% yield): ${ }^{1} \mathrm{H}$ NMR (MeOH, $\left.400 \mathrm{MHz}\right): \delta, 1.31(\mathrm{t}, 24 \mathrm{H}, J=7.0 \mathrm{~Hz}), 1.37(\mathrm{~m}, 4 \mathrm{H}), 1.45(\mathrm{~m}, 4 \mathrm{H}), 1.78(\mathrm{~m}, 4 \mathrm{H}), 2.12(\mathrm{~m}, 2 \mathrm{H}), 2.27(\mathrm{~m}$, $2 \mathrm{H}), 3.70(\mathrm{~m}, 8 \mathrm{H}), 4.91(\mathrm{~d}, 1 \mathrm{H}, J=10.4 \mathrm{~Hz}), 5.08(\mathrm{~m}, 2 \mathrm{H}), 5.15(\mathrm{~d}, 1 \mathrm{H}, J=16.8 \mathrm{~Hz}), 5.42(\mathrm{~m}, 1 \mathrm{H}), 5.68(\mathrm{dt}, 1 \mathrm{H}, J=8.0,15.2 \mathrm{~Hz}), 6.05$ $(\mathrm{m}, 2 \mathrm{H}), 6.29(\mathrm{ddd}, 1 \mathrm{H}, J=10.0,10.0,16.6 \mathrm{~Hz}), 6.65(\mathrm{ddd}, 1 \mathrm{H}, J=10.0,10.5,16.6 \mathrm{~Hz})$. Integrations are reported such that the olefinic protons are calibrated to 1 . Thus, integrations for protons in which the cis- and trans- isomers overlap provide twice the signal. HRMS (MALDI-TOF MS+) calculated for $\mathrm{C}_{40} \mathrm{H}_{51} \mathrm{~N}_{4} \mathrm{O}_{2}\left([\mathrm{M}]^{+}\right)$619.4012, found 619.4038.

\section{Determination of the degradation pathway of (1).}

Rhodamine diene $\mathbf{3}$ was synthesized to confirm the degradation pathway of $\mathbf{1}$ under protein modification conditions (Figure S1).

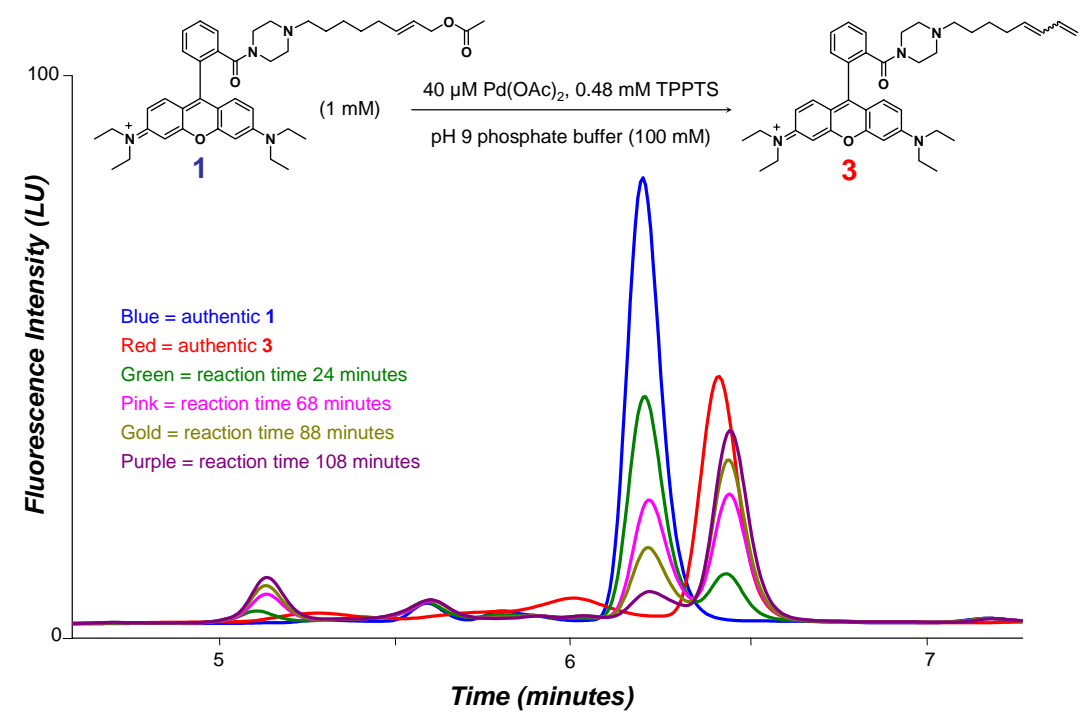

Figure S1. HPLC fluorescence trace of 1 under the reaction conditions for protein modification. Excitation wavelength $=530 \mathrm{~nm} ;$ emission wavelength $=570 \mathrm{~nm}$.

Preparation of catalyst/ligand solution for protein modification reactions. To a vial charged with $3 \mathrm{mg}$ of $\mathrm{Pd}(\mathrm{OAc})_{2}$ and $91 \mathrm{mg}$ of TPPTS (1:12

$\mathrm{Pd} /$ ligand) was added $1.6 \mathrm{~mL}$ of distilled water. The heterogeneous mixture was sparged with argon for 1 minute, and then sonicated briefly to facilitate the solvation of the $\mathrm{Pd}(\mathrm{OAc})_{2}$ clumps. The solution was again sparged with argon for an additional 30 minutes to yield a homogeneous bright yellow solution. This solution was stored in sealed ampules under argon or freshly prepared for each protein modification reaction.

Modification of $\boldsymbol{\alpha}$-Chymotrypsinogen A (200 $\boldsymbol{\mu M})$. To a $1.5 \mathrm{~mL}$ eppendorf tube was added $100 \mu \mathrm{L}$ of a $2 \mathrm{mM}$ aqueous solution of $\alpha$ chymotrypsinogen A (final concentration $=200 \mu \mathrm{M}, 1$ equiv.), $71.5 \mu \mathrm{L}$ of a $14 \mathrm{mM}$ aqueous solution of rhodamine 1 (final concentration $=$ $1 \mathrm{mM}, 5$ equiv. $), 5.6 \mu \mathrm{L}$ of an aqueous solution of the catalyst mixture $\left(7 \mathrm{mM}\right.$ in $\operatorname{Pd}(\mathrm{OAc})_{2}, 1: 12 \mathrm{Pd}$ :TPPTS; final concentration $=40 \mu \mathrm{M}$ $\mathrm{Pd}(\mathrm{OAc})_{2}, 0.2$ equiv.; $480 \mu \mathrm{M}$ TPPTS, 2.4 equiv.) and $823 \mu \mathrm{L}$ of $100 \mathrm{mM}$ triethylammonium carbonate or phosphate buffer (pH 8.6). The 
reaction mixture was incubated at room temperature for 45 minutes and then applied to a NAP-5 gel filtration column that had been equilibrated with 3 column lengths of $\mathrm{ddH}_{2} \mathrm{O} .500 \mu \mathrm{L}$ of the protein reaction mixture was eluted with $1 \mathrm{~mL}^{\circ} \mathrm{ddH}_{2} \mathrm{O}$ to yield a deep purple solution that was nearly free of small molecules. The small amount of dye that remained was removed by a second gel filtration column or dialysis. The purified protein mixture was then analyzed by SDS-PAGE with fluorescence visualization and by ESI-MS. Note: It was not necessary to remove the small molecules prior to gel analysis. The portion of the gel that contained free dye was excised immediately following removal of the gel from its plastic casing to ensure that free dye did not diffuse out and inadvertently stain the protein bands.

Interestingly, $\alpha$-chymotrypsinogen A that had been doubly lipidated (employing carbamate 10) remained completely water soluble. We speculate that this is due to the formation of protein aggregates that help to shield the highly hydrophobic chains from the solvent. A small amount of precipitation was observed upon gel filtration purification of farnesylated $\alpha$-Chymotrypsinogen A. However, it was a not a significant amount of protein loss and it did not inhibit analysis of the protein mixture or further experiments.

Validation of ESI-MS as a Quantitation Method for Modified $\boldsymbol{\alpha}$-Chymotrypsinogen A. A sample of chymotrypsinogen A was modified with 1 as described above. After removal of the small molecules using gel filtration through a NAP-5 column, the level of conversion was determined using ESI-MS analysis (Figure S2a). The same sample was also analyzed by RP-HPLC, which separated the unmodified, singly-modified, and doubly-modified protein components (Figure S2b). Each of these species was readily identifiable by its UV spectrum. The area of each peak was determined by tryptophan fluorescence, with excitation at $295 \mathrm{~nm}$ and monitoring at $340 \mathrm{~nm}$. The absorbance at $280 \mathrm{~nm}$ was also used for the integration of the peaks on the chromatogram. To account for the residual UV absorbance of the rhodamine chromophore at $280 \mathrm{~nm}$, a correction factor was generated through the UV analysis of $\mathbf{1}$, which afforded a ratio of 0.178 for the absorbance at $280 \mathrm{~nm}$ compared to the absorbance at $555 \mathrm{~nm}$. The application of this value to the peak areas yielded the corrected integration values, which were in excellent agreement with the tryptophan fluorescence data. All values agreed with the ESI-MS ratios to within $10 \%$.

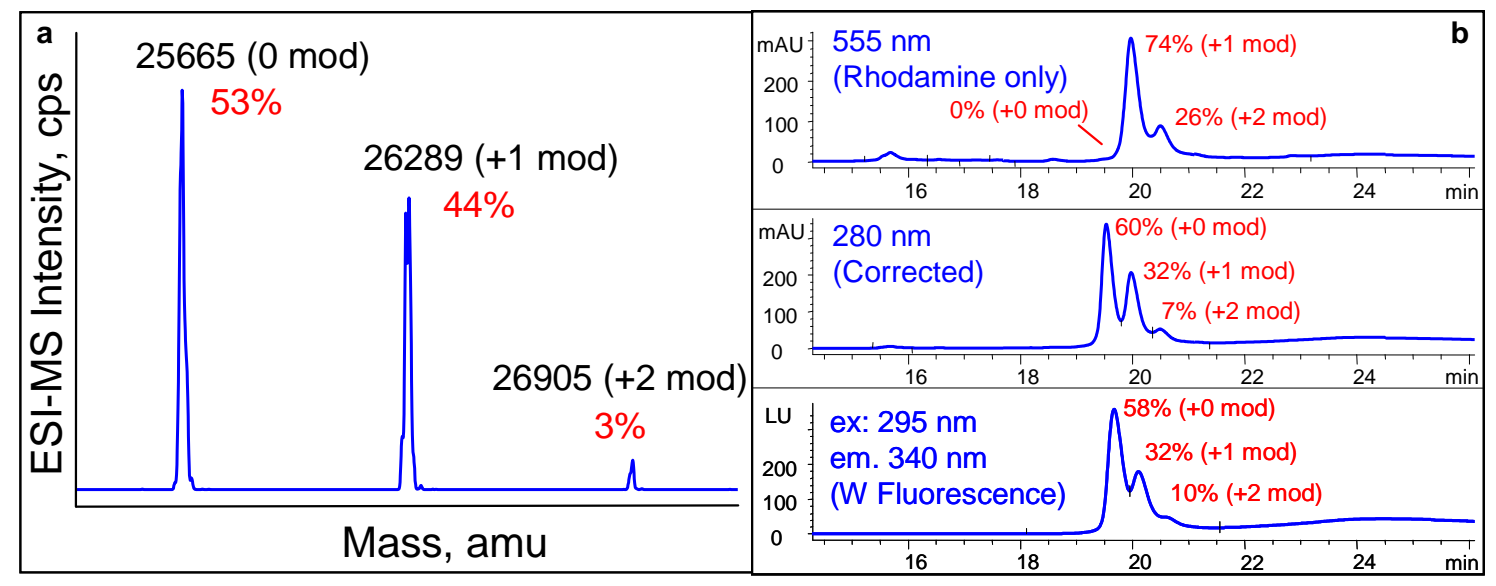

Figure S2.

Procedure for Trypsin Digestion of $\alpha$-Chymotrypsinogen A. $5.0 \mu \mathrm{L}$ of the gel filtration (NAP-5) purified protein reaction mixture was treated with $5.0 \mu \mathrm{L}$ of $t \mathrm{BuOH}$. DTT was added to a final concentration of $10 \mathrm{mM}$ and the solution was heated at $65^{\circ} \mathrm{C}$ in a heat block for 15 minutes. The denatured protein sample was diluted with $40 \mu \mathrm{L}$ of $50 \mathrm{mM} \mathrm{NH}_{4} \mathrm{HCO}_{3}$ buffer $(\mathrm{pH} 7.8$ ) and treated with $2.0 \mu \mathrm{L}$ of a solution of sequencing grade modified trypsin (Promega, $20 \mu \mathrm{g}$ reconstituted with $150 \mu \mathrm{L}$ of $50 \mathrm{mM}$ acetic acid). The digest mixture was then incubated at $37{ }^{\circ} \mathrm{C}$ for $12 \mathrm{~h}$. The crude digest mixture was desalted using a $\mu \mathrm{C} 18$ ZipTip ${ }^{\circledR}$ pipet tip. The desalted protein mixture was then analyzed by MALDI-TOF MS. 
The observed fragments are as follows: T2 (residues 16-36) IVNGEEAVPGSWPWQVSLQDK (expected mass = 2340, observed mass = 2341); T3 (residues 37-79) TGFHFCGGSLINENWVVTAAHCGVTTSDVVVAGEFDQGSSSEK (expected mass = 4445, observed mass $=4444$ ); T10 (residues 108-145) LSTAASFSQTVSAVCLPSASDDFAAGTTCVTTGWGLTR (expected mass =3781, observed mass = 3780); T12 (residues 155-169) LQQASLPLLSNTNCK (expected mass =1630, observed mass = 1630); modified T14-T15 (residues 171-177) YWGTKIK (expected mass $+620=1515$, observed mass $=1516$ ). 620 is the expected mass increase for the protein after modification with rhodamine $\mathbf{1}$, following loss of acetate.

Labeling of Cysteine 181 of H-Ras C118S (Residues 1-181) with Oregon Green Maleimide (S11). To a solution of $100 \mu \mathrm{M}$ H-Ras C118S (Residues 1-181) was added a solution of Oregon Green Maleimide (S10, final concentration $1 \mathrm{mM}$ ) at room temperature for 65 minutes in $100 \mathrm{mM}$ phosphate buffer, $\mathrm{pH}$ 6. The reaction mixture was diluted with loading buffer containing DTT and applied directly to an SDS-PAGE gel without further purification.

Preparation of small unilamellar vesicles (SUVs). To a $50 \mathrm{~mL}$ roundbottom flask, which had been thoroughly cleaned with piranha solution, was added $600 \mu \mathrm{L}$ of a solution of egg phosphatidyl choline in $\mathrm{CHCl}_{3}(10 \mathrm{mg} / \mathrm{mL})$ and $400 \mu \mathrm{L}$ of additional $\mathrm{CHCl}_{3}$. The solvent was evaporated on a rotary evaporator and the flask was placed in a dessicator under vacuum for 1 hour. $1 \mathrm{~mL}$ of ddH $\mathrm{H}_{2} \mathrm{O}$ was added and the flask was incubated at room temperature for 2 hours with occasional swirling. At this time, all of the solids had become suspended and the solution was cloudy. This solution was then passed through an extruder equipped with $100 \mathrm{~nm}$ filter paper ten times, resulting in a cloudy solution of $100 \mathrm{~nm}$ SUVs $(6 \mathrm{mg} / \mathrm{mL})$.

General procedure for incorporation of lipidated proteins into SUVs. To a $1.5 \mathrm{~mL}$ eppendorf tube was added $25 \mu \mathrm{L}$ of a $100 \mu \mathrm{M}$ mixture of $\mathbf{4 a}, \mathbf{4 c}$, and $\mathbf{4 d}$ (resulting from the reaction of $\mathbf{4 a}$ with 9 ), $25 \mu \mathrm{L}$ of $6 \mathrm{mg} / \mathrm{mL}$ SUV solution, and $25 \mu \mathrm{L}$ of a $6 \mathrm{mg} / \mathrm{mL}$ aqueous solution of $\beta$-octyl-D-glucopyranoside. The solution was incubated at room temperature for 20 minutes and then applied to S-1000 gel filtration resin that had been equilibrated with three column volumes of $\mathrm{ddH}_{2} \mathrm{O}$. The flow-through was then analyzed by SDS-PAGE.

\section{$\underline{\text { References }}$}

${ }^{1}$ Laemmli, U. K. Nature 1970, 227, 680.

${ }^{2}$ Nguyen, T.; Francis, M. B. Org. Let. 2003, 5, 3245-3248.

${ }^{3}$ Uziel, J.; Riegel, N.; Aka, B.; Figuière, P.; Jugé, S. Tet. Let. 1997, 38, 3405-3408.

${ }^{4}$ Tagaki, W.; Inoue, I.; Yano, Y.; Okonogi, T. Tet. Let. 1974, 30, 2587-2590.

${ }^{5}$ Sato, F.; Suzuki, Y.; Sato, M. Tet. Let. 1982, 23, 4589-4592.

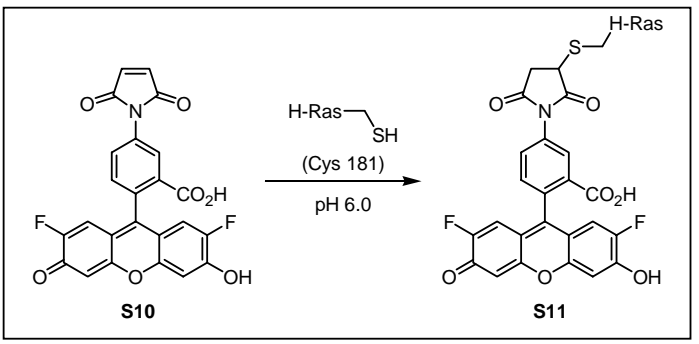

